\title{
Instagram as a tool for disseminating sustainable practices: an experience report
}

\author{
Yasmin Coelho de Freitas' ${ }^{(1 D}$, Francisco de Assis Ferreiral ${ }^{(i D}$, Carlos Eduardo Batista \\ Groner $^{(\mathbb{D})}$, Igor Tristão Azevedo' ${ }^{(\mathbb{D})}$, Jacqueline Rogéria Bringhenti' ${ }^{(i)}$ Adriana Marcia'
}

'Federal Institute of Education, Science and Technology of Espirito Santo, Vitória, ES, Brazil

\begin{abstract}
The social isolation promoted by COVID-19 impacts the routine and habits of families with a reflection on the characteristics and generation of solid waste and consumption of natural resources. This situation has been identified as an opportunity for educational institutions to promote awareness actions with their internal and external community as a contribution to reduce such effects. In order to disseminate sustainable practices related to the daily life of the pandemic and to evaluate responses, the group of teachers and students developed activities which contributed to minimize the effects of the pandemic. The ease and speed of social media was used as a tool for actions. The methodological steps were: survey of the existing contents in the official networks of the Federal Institute of Espirito Santo related to the topic of interest, the definition of the InstagramTM social network, profile creation for the Ifes Biotechnology and Sustainability Laboratory (Labiotecs), increase of followers, creation and dissemination of content and publications analysis. The work is based on the Deming cycle methodology in order to optimize its planning and execution. Among the results, 179 followers on the profile were reached, 10 posts were shared in the feed, 4 quizzes and 5 polls applied until $06 / 17 / 2020$. The effectiveness of the work was shown through the reach of publications and public acceptance. Also, the Deming cycle proved to be adequate and capable of being replicated.
\end{abstract}

Keywords: Social media; Sustainable development; Environmental education; Communication Technology

\section{RESUMO}

O isolamento social promovido pela COVID-19 tem resultado em uma expansão considerável no tempo em que pessoas passaram a ficar em suas casas, ocasionando um aumento nos resíduos gerados. Esta situação representa uma janela de oportunidade para que instituições de ensino promovam ações de sensibilização junto a sua comunidade interna e externa como contribuição para reduzir tais impactos. Neste sentido, aproveitando a facilidade e velocidade de acesso à informação via redes sociais com o objetivo de divulgar práticas sustentáveis relacionadas ao manejo de resíduos durante a pandemia, o presente trabalho teve sua metodologia baseada nas seguintes etapas: realização de um levantamento sobre os conteúdos já existentes nas redes oficiais do Instituto Federal do Espírito Santo relacionados ao assunto, a definição da rede social InstagramTM, criação do perfil para o Laboratório de Biotecnologia e Sustentabilidade (Labiotecs) do Ifes, 
captação de seguidores, criação e divulgação dos conteúdos e análises das publicações. O trabalho está fundamentado na metodologia do ciclo de Deming (Plan-Do-Check-Act) a fim de otimizar seu planejamento e execução. Entre os resultados, foram alcançados 179 seguidores no perfil, compartilhados 10 publicações no feed, 4 quizzes e 5 enquetes até o dia 17/06/2020. A efetividade do trabalho se mostra por meio do alcance das publicações, revelando a grande aceitação do público aos temas abordados, além de que também foi observado que um número elevado de seguidores que desconhecem assuntos importantes relacionados à sustentabilidade, destacando a importância do perfil na divulgação de conhecimentos científicos.

Palavras - Chave: Redes sociais; Desenvolvimento sustentável; Educação ambiental; Tecnologia da informação e comunicação

\section{INTRODUCTION}

COVID-19, arising from the new SARS-CoV-2 virus (popularly known as Coronavirus), is an acute respiratory disease that emerged in China in 2019, quickly becoming an international public health problem (MAUCH et al., 2020).

With the significant increase in the rate of infection worldwide, the World Health Organization (WHO) has classified the disease as pandemic, recommending social isolation measures to contain the spread of the virus, resulting in a considerable expansion of the time people spend inside their homes.

The phenomenon established new models of work at home (home office) as well as made the use of Information and Communication Technologies (ICTs) more frequent, in order to expand communication with the outside world and bring a new way of strengthening links between people in the period.

The World Health Organization (WHO) recommended measures to prevent and control the disease to people who cannot comply with social isolation, such as the use of personal protective equipment (PPE's), constant hand hygiene and in cases of suspected or contaminated individuals by the coronavirus, isolation in quarantine (WORLD HEALTH ORGANIZATION, 2020).

Social isolation caused changes in the generation and characteristics of household solid waste, given the high number of people who remain in their homes full time (PUGLIESI, SANTIAGO, LEITE, 2020). In this context, the WHO also issued guidelines in relation to waste management in this period in order to avoid the possibility of contamination when in contact with different materials, due to risks associated with the characteristic of the virus that may 
adhere to inanimate surfaces, such as paper and plastic for up to nine days (KAMPF et al., 2020; VAN DOREMALEN et al., 2020; WORLD HEALTH ORGANIZATION, 2020).

In Brazil, the control of the disease is hampered by many factors, such as the conditions of social inequality and access to housing and sanitation, which make families vulnerable to the virus (BARRETO et al., 2020). Added to this is the distortion of information on prevention methods and the sharing of false news on social media platforms that hinder the fight against the disease and contribute to the increase of COVID-19 cases in the country.

In this scenario, the role of researchers and educational institutions in the dissemination of reliable information in line with scientific knowledge and the principles of critical environmental education, becomes increasingly important in order to allow relevant socio-environmental transformations and promote reflections on both individual and collective responsibility at local and global levels (TOZONI-REIS, 2006). Actions aimed at conscious consumption, selective waste collection and valorization of organic waste is indispensable in the current scenario. These actions also collaborate directly with the Sustainable Development Goals (SDGs) stipulated in the 2030 agenda created in 2015 by the United Nations (UN), minimizing both environmental and public health problems related to the final disposal of waste in landfills and dumps (MACEDO, CAMPOS, 2015; OLIVEIRA et al., 2020).

Taking advantage of ICTs, environmental education appears as a fundamental instrument in the construction of sustainable societies, stimulating the development of practices that minimize the risks of contamination and promote socio-environmental sustainability (SOUSA JÚNIOR et al., 2020)

According to Caritá, Padovan and Sanches (2011), social networks can favor the learning process, making it interactive by the use of media such as videos, audios and hypertexts which provide new ways of learning and exceeding the limits of the classroom. In this context, social networks can be used as a repository of content, allowing students to review and reinforce topics discussed in formal teaching environments, in addition to serving as a source of knowledge for individuals interested in the subject (WERHMULLER, SILVEIRA, 2012). 
With regard to social networks, Parra et al. (2019) used social networks as an environmental education tool, seeking to sensitize the academic community and promote selective waste collection at the Federal Technological University of Paraná - Londrina campus (UTFP-LD). From the dissemination of sustainability images on FacebookTM and InstagramTM, the authors concluded the effectiveness of this strategy, due to the high number of interactions and reach of publications.

Thus, the use of social networks for scientific dissemination is a viable alternative to promote informal environmental education actions in the current context, given the ease of access to a wide audience, and the possibility of disseminating quality content in a simple, fast, and remote way (GOHN, 2006).

Among the basic principles foreseen in the National Environmental Education Policy (Law 9.795/1999), the guarantee of continuity and permanence of educational actions stands out, emphasizing the importance of developing methodologies that allow the follow-up in the teaching process (BRASIL, 1999).

Among the tools used to assist the planning and execution of activities in communication vehicles, the Deming cycle or PDCA stands out, which allows maintenance and continuous improvement of strategic processes, through a circuit composed of four actions: (P) Plan, (D) Do, (C) Check and (A) Act (CAMPOS, 1992).

The PDCA cycle is widely used by companies to carry out strategic planning. Despite its frequent use in business management, the tool can be used in any organizational process, such as digital marketing, facilitating its execution (ALMEIDA, FERREIRA, FONSECA, 2019). Regarding teaching, Pimentel, Le Boudec and Leal (2007) used the tool for structuring classes in the engineering course at UDESC - University of the state of Santa Catarina, confirming its functionality in the implementation of innovations and continuous improvements, promoting success in higher education.

In this way, this tool can facilitate the development of environmental education activities via social networks, allowing to identify problems and propose solutions, thus promoting their continuity. 
Based on the recommendations of health agencies on the importance of the correct management of generated waste, educational institutions have at their disposal an array of opportunities to assume a leading role in the dissemination of sustainable and safe practices and in production of sufficient scientific knowledge to be used and transmitted with competence to those who deal with daily generated waste in homes.

Based on this precept, teachers and students of Practices in Sustainable Development discipline of the Postgraduate Program in Sustainable Technologies of Ifes were encouraged to develop actions that related the sustainability theme to the current Brazilian socioenvironmental and health reality, taking advantage of the ease and speed of access to information via social networks. In this sense, the objective of this work is to report an experience of dissemination in sustainable practices related to the management of residues generated during the COVID-19 pandemic, in the light of the principles of Critical Environmental Education. For this, a profile on the social network InstagramTM was created for the Ifes Biotechnology and Sustainability Laboratory (Labiotecs), applying the PDCA cycle in the process of elaborating and executing the work.

\section{MATERIAL AND METHODS}

The work consists of an experience report, in which it is proposed to describe actions carried out by students and teachers of Practices in Sustainable Development discipline, of the Postgraduate Program in Sustainable Technologies (PPGTECS) of the Federal Institute of Espirito Santo. The activities were developed remotely between 05/12/2020 and 09/07/2020, via web conferencing applications and social networks (Skype, WhatsApp and Instagram), using Information and Communication Technologies.

To optimize the planning and execution of the research, the PDCA cycle quality tool was used (Figure 1). In the planning phase (Plan), it was possible to define the theoretical framework, develop the research methodology, select the social network and the content to be disseminated. In the development phase, actions were taken to get followers on the social network, post content and compile data (Do). The results obtained went through analysis 
and discussion (Check) and strategies were drawn up to increase the number of followers and provide improvements in the dissemination of content (Act).

Figure 1. PDCA cycle for research development

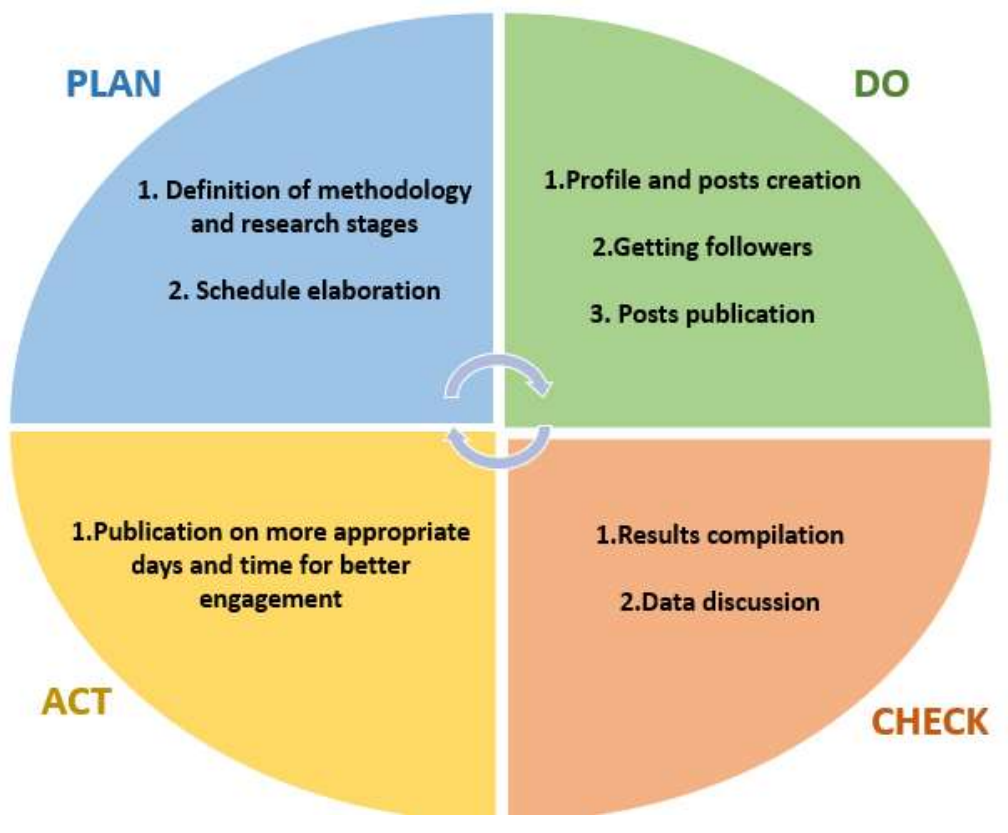

Source: Modified from ISO 14001 (2015).

\subsection{Survey of contents related to sustainability on IFES profiles}

A survey was carried out on the official page of land on pages of the other IFES campuses on Instagram, with the objective of identifying posts with the sustainability theme, the frequency of posting and the approach, whether direct or indirect, used in the in publications. The approach of the three dimensions of sustainability (social, environmental, and economic) was also verified in the publications. After the survey, a diagnosis was made to identify some common characteristic among the institution's social media.

\subsection{Definition of social network and profile creation}

Based on the diagnosis of Ifessocial networks, the creation of a profile for IfesBiotechnology and Sustainability Laboratory (Labiotecs) was defined in view of its history of activities involving sustainable practices, environmental education, and its connection with society through research and extension projects. The construction of an Instagram page 
was defined due to the versatility of the social network for creating dynamic content in the form of images or videos, in addition to being one of the most accessed social networks worldwide (WE ARE SOCIAL AND HOOTSUITE, 2017). Added to this is the fact that Instagram allows the creation of professional accounts for more complete analyzes on the reach of the publications made. The Labiotecs profile photo was built with the help of the online tool Canva, with the selection and adaptation of images deliberated by Labiotecs members in a WhatsApp group.

\subsection{Getting followers}

In order to attract followers, the profile of Labiotecs was initially disseminated in research groups in the WhatsApp application which contained students, teachers and people connected to Ifes Subsequently, the disclosure was also made through invitations sent to the researchers' individual contacts by the sharing of Labiotecs publications on their personal profiles on Instagram.

\subsection{Content creation and dissemination}

The contents published on the Labiotecs page emerged from a brainstorming exercise on topics relevant to the Brazilian socio-environmental and health context in the period of social isolation and pandemic of COVID-19, based on bibliographic research and discussions made by the group of researchers during the classes in the discipline of Practices in Sustainable Development. The publications address the activities developed at Labiotecs, sustainable practice issues, personal protective equipment usage (PPE's), Agenda 2030 and SDGs and the final disposal of solid urban waste in the light of the principles of environmental education.

Since the Instagram platform offers a variety of ways to post content, it was decided to divide them into posts in the feed, in which followers are allowed to like, share and comment on publications and posts in story format (stories), which provide temporary interactions between users through photos, videos, polls and questionnaires. Although 
temporary, stories can be fixed in the creator's profile through bookmarks, in the form of highlights, allowing the viewing of content for unlimited time (SILVA, FILHO, FREIRE, 2018).

To measure the interaction and engagement of followers of the Labiotecs profile and to promote an understanding of the topics covered in the feed posts, publications were made in the stories in the form of polls and quizzes once the use of this resource could encourage thinking, research, reflection and discussion about the contents and concepts transmitted in a theoretical or practical way.

The creation and editing of images and arts published in publications were developed with the help of the online design tool Canva.

\subsection{Analysis of publications}

A publication schedule was organized with dates, topics covered, titles and the type of posts. Information on the impact of publications was obtained using metrics available on the social network Instagram, from 05/12/2020 to 06/20/2020. A simple descriptive analysis is performed based on the number of followers, reach of publications and user interaction, through questionnaires and surveys. Simple descriptive statistics was used since the profile evaluated is new with a number of followers still in progress. With the consolidation of the profile, it is intended to conduct new research using more advanced statistical methods to better represent the data.

\section{RESULTS AND DISCUSSION}

In view of the initial diagnosis of the official Ifesprofiles on Instagram, no publications related to sustainability and awareness of its followers were identified. However, it was possible to observe in the researched pages that the official channels have the purpose of institutional communication of events, general reports and tributes. It was identified though, that few posts indirectly covered the subject, either in the form of dissemination of actions performed by the institution or events without the intention of inducing reflection or without an environmental educational purpose. Specifically, on the Vitória campus page, no publications that fit the theme were found, even indirectly, which illustrates the relevance of the research. 
From the initial survey, the profile of Labiotecs on the social network Instagram was created, having the profile photo (Figure 2) built, selected, and adapted collectively through discussions in WhatsApp, making possible the choice of the most representative image. The profile was released to the public, both through the sharing of publications in groups of WhatsApp application as well as in the research participants profiles.

After extensive discussion and considering the relevant information to Sustainable Development Practices discipline, the content of the publications was created addressing the following themes: importance of personal protective equipment (PPE); urban solid waste management; and sustainability during social isolation. According to the data provided by Instagram, it was found that in the forty days since its creation, the Labiotecs profile has reached 179 followers with10 posts made in the feed, 4 quizzes and 5 polls performed until the 17 th of June 2020.

Figure 2. Labiotecs profile image for Instagram social network

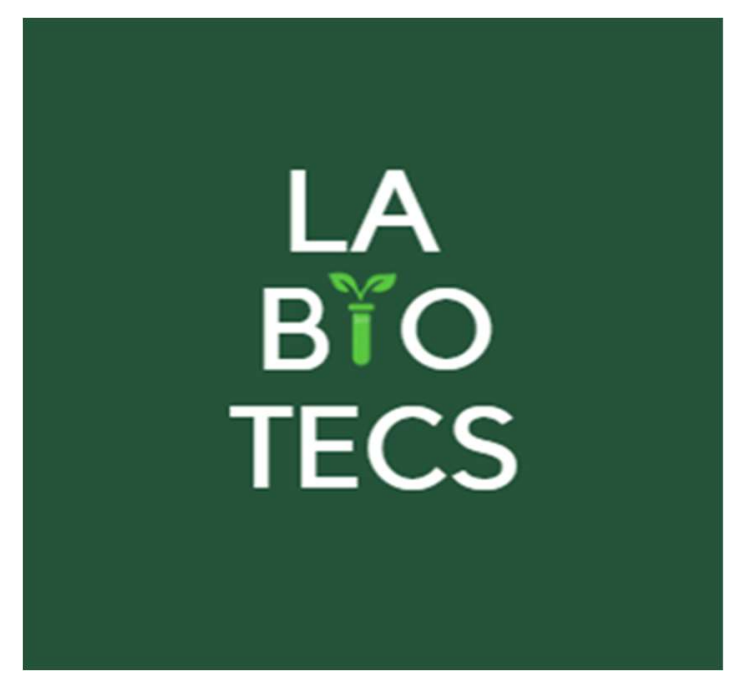

Source: Authors (2021)

Among the publications made in the feed, it was possible to observe that on May 23, there was an evolution in the number of followers reached as new publications were made (Figure 3), reaching the mark of 190 users with the publication made on 06/17/2020.

Figure 3. Reach of publications made in the feed 


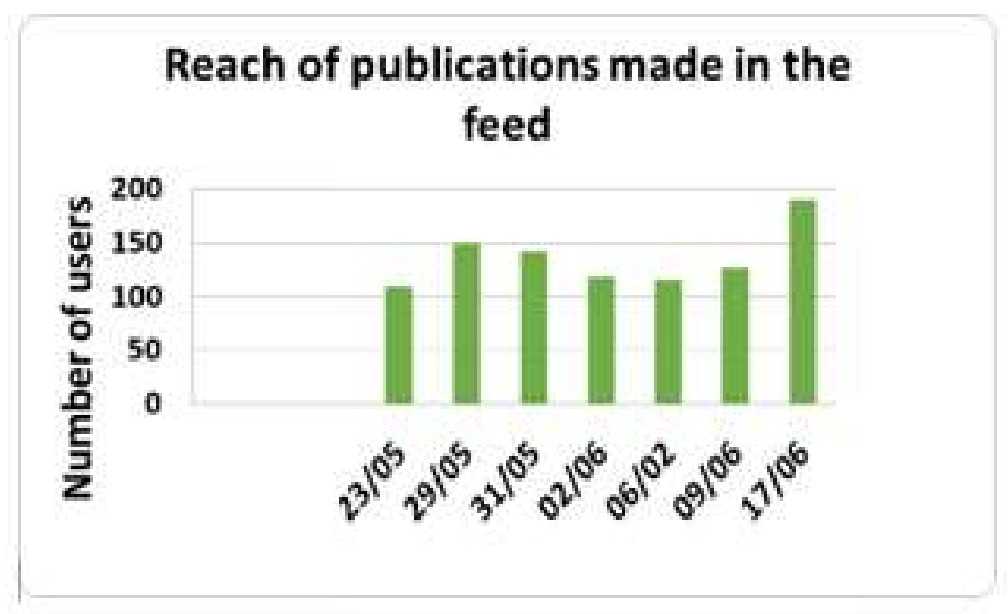

Source: Authors (2021)

Regarding the 4 sustainability quizzes (Table 1), it was found that the more familiarized participants were with the proposed themes the higher was their interaction. The percentage of correct answers in the proposed sentences presented an average of $81.0 \%$ among 57 responses. Figure 4 shows the percentage of correct answers obtained in each quiz.

Table 1. Sustainability quizzes

\begin{tabular}{|c|c|c|}
\hline $\begin{array}{c}\text { Quiz } \\
\text { number }\end{array}$ & Question & Options \\
\hline
\end{tabular}

a) Use only disposable masks

\begin{tabular}{|c|c|c|}
\hline \multirow{3}{*}{1} & \multirow{3}{*}{$\begin{array}{c}\text { An example of } \\
\text { a sustainable } \\
\text { attitude }\end{array}$} & b) Wear surgical gloves \\
\hline & & c) Discard the masks in a plastic bag \\
\hline & & $\begin{array}{l}\text { d) Wear the same mask throughout } \\
\text { the day }\end{array}$ \\
\hline \multirow{3}{*}{2} & \multirow{3}{*}{$\begin{array}{l}\text { Which type of } \\
\text { mask is most } \\
\text { sustainable? }\end{array}$} & a) Surgical mask (common) \\
\hline & & b) Mask N95 \\
\hline & & c) Fabric mask \\
\hline
\end{tabular}




\begin{tabular}{|c|c|c|}
\hline \multirow{4}{*}{3} & \multirow{4}{*}{$\begin{array}{l}\text { What's the } \\
\text { correct way to } \\
\text { reduce the } \\
\text { volume of } \\
\text { waste at home? }\end{array}$} & $\begin{array}{l}\text { a) Crushing plastic bottles and } \\
\text { aluminum cans }\end{array}$ \\
\hline & & $\begin{array}{l}\text { b) Washing, draining and } \\
\text { compacting milk cartons }\end{array}$ \\
\hline & & $\begin{array}{l}\text { c) Disassembling the cardboard } \\
\text { and/or Styrofoam packaging }\end{array}$ \\
\hline & & d) All of these forms are correct \\
\hline \multirow{4}{*}{4} & \multirow{4}{*}{$\begin{array}{l}\text { How to be } \\
\text { sustainable } \\
\text { with your } \\
\text { garbage? }\end{array}$} & $\begin{array}{l}\text { a) Separating organic waste from } \\
\text { recyclable and non-recyclable }\end{array}$ \\
\hline & & $\begin{array}{l}\text { b) Disposing glass containers } \\
\text { separately }\end{array}$ \\
\hline & & $\begin{array}{c}\text { c) Reducing and/or reusing } \\
\text { packaging }\end{array}$ \\
\hline & & d) All are sustainable forms \\
\hline
\end{tabular}

Source: Authors (2021)

Figure 4. Percentage of correct answers in the quizzes

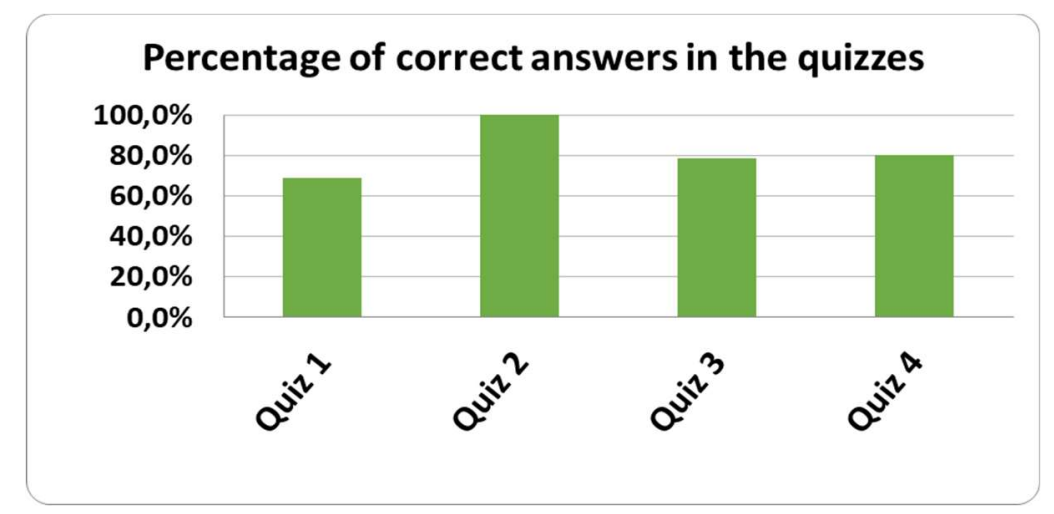

Source: Authors (2021)

As for the polls (Table 2), there was a smaller number of interactions in relation to the total followers of the profile. The results show that almost half of the followers participating in the interaction are unaware of topics involving the concept of Sustainable Development, such as Agenda 2030 and the SDGs. On the other hand, with less participation in the question about the use of protective masks, $100 \%$ of participants in the survey responded that they 
wear reusable fabric masks, thus collaborating to the reduction of waste and consequently to sustainability.

As a parallel result, there is the possibility to review and expand Labiotecs' actions, based on the information collected following the established PDCA cycle.

Table 2. Polls conducted

\begin{tabular}{|c|c|c|c|c|}
\hline Date & Question & Option 1 & Option 2 & $\begin{array}{c}\text { Total } \\
\text { answers }\end{array}$ \\
\hline $05 / 27$ & $\begin{array}{l}\text { Do you know what the } \\
2030 \text { Agenda is? }\end{array}$ & Yes 53\% & No $47 \%$ & 15 \\
\hline $05 / 27$ & $\begin{array}{c}\text { Do you know what SDGs } \\
\text { are? }\end{array}$ & Yes 53\% & No $47 \%$ & 15 \\
\hline 06/03 & $\begin{array}{c}\text { What kind of mask do } \\
\text { you wear? }\end{array}$ & $\begin{array}{c}\text { Reusable } \\
100 \%\end{array}$ & $\begin{array}{c}\text { Disposable } \\
0 \%\end{array}$ & 8 \\
\hline 06/03 & $\begin{array}{c}\text { Do you develop any } \\
\text { sustainable practices with } \\
\text { your garbage? }\end{array}$ & Yes 25\% & No $75 \%$ & 8 \\
\hline 06/08 & $\begin{array}{l}\text { Do you know the } \\
\text { recommendations for } \\
\text { waste management in } \\
\text { case of contamination by } \\
\text { COVID19? }\end{array}$ & Yes 25\% & No $75 \%$ & 4 \\
\hline
\end{tabular}

Source: Authors (2021)

With the bibliographic survey, it was possible to verify the importance of creating a page that directly addresses the context of sustainable practices and expresses its importance for society. Given the moment of health crisis, it becomes even more urgent the dissemination scientific knowledge.

Regarding the planning, execution, and dissemination of activities, the PDCA tool proved to be important in this study. The PDCA allowing the optimization of steps followed throughout the process, highlighting its application as a resource aimed at structuring environmental education activities. This fact cooperates with the principle of continuity and 
permanence of educational actions, granted in the National Environmental Education Policy (BRASIL, 1999).

In addition, the tool provided the delimitation of strategies that optimized the dissemination of content, such as the use of hashtags on the topic of posting and the tagging of official Ifesprofiles, which expanded the reach of publications, allowing other institutions, users and project linked to sustainability to start following the Labiotecs profile.

Regarding the results obtained in polls about PPE's, it can be deduced that the followers' knowledge about personal protective equipment is the result of constant communication campaigns by the media. This result collaborates with what was observed by Chan et al (2020), who found an increase in the use of social networks, such as TwitterTM and WeChatTM, to access news about COVID-19, given the practicality, speed and free sharing of information.

The results of the survey on sustainable practices with garbage emphasized that three quarters of followers do not develop or are unaware of sustainable practices in the management of generated waste, especially in relation to contaminated waste, which highlights the importance of content dissemination on the correct management of waste and its valorization, therefore promoting a new perspective about generated residues in the individuals residence. In addition, the dissemination of these practices directly collaborates with the achievement of objective 12 of the UN Agenda 2030, which deals with responsible consumption and production, seeking to build sustainable societies (PROGRAMA DAS NAÇÕES UNIDAS PARA O DESENVOLVIMENTO - PNUD, 2015).

Another point to be considered is the contribution to the training of professionals in the environmental studies field, such as students in the Master's Program in Sustainable Technologies. The team involved considered the use of the social network Instagram as a viable resource for the dissemination of environmental education actions, highlighting the relevance of publications and discussion of topics related to the correct disposal of PPE, which significantly contributed to the transmission of scientific knowledge and practices that collaborate with the construction of sustainable societies. 


\section{CONCLUSION}

The main objective of this research was to disseminate sustainable practices related to the daily life of the pandemic, reporting the answers and the experience lived by the researchers. Thus, the effectiveness of the work was demonstrated through the reach of the publications made and the great public acceptance of the presented topics.

t was observed that $75 \%$ of the followers who participated in the research are unaware of important topics related to sustainability, highlighting the importance of the page in the dissemination of scientific knowledge. In addition, the PDCA cycle proved to be adequate for the planning and execution of activities, helping to adapt the methodology for better dissemination of publications, which can be used in other researches with similar objectives.

Regarding the Instagram social network, the researchers highlight the following advantages: practicality of use, instant access to publications, diversity and free sharing of information, and enabling of its strategic use as a non-formal or informal resource for Environmental Education. This experience contributed to the training of students involved in the research, providing relevant experiences on environmental education and scientific dissemination.

\section{REFERENCES}

Almeida CF, Ferreira MJS, Fonseca MMP. Logística de serviço: utilização de mídias digitais como estratégia para fidelização da marca. Amazon Live Journal, 2019; 1 (2); p. 1-12.

Barreto ML, Barros AJD, Carvalho MS, Codeço CT, Hallal PRC, Medronho RA, Struchiner CJ, Victora CG, Werneck GL. O que é urgente e necessário para subsidiar as políticas de enfrentamento da pandemia de COVID-19 no Brasil?. Revista Brasileira de Epidemiologia, 2020; 23.

Brasil.Lei no 9.9795, de 27 de abril de 1999. Estabelece a Política Nacional de Educação Ambiental. Diário Oficial [da] República Federativa do Brasil, Poder Executivo, Brasília, DF, 27 abr. 1999.

Campos VF. Controle da Qualidade Total (no estilo japonês). Bloch, 1992.

Caritá EC, Padovan VT, Sanches LMP. Uso de redes sociais no processo ensinoaprendizagem:avaliação de suas características. Anais do 170 Congresso Internacional ABED de Educação a Distância: São Paulo, 2011. 
Chan AKM, Nickson CP, Rudolph JW, Lee A, Joynt GM. Social media for rapid knowledge dissemination: early experience from the COVID-19 pandemic. Anaesthesia, 2020.

We are social and hootsuite: global overview, 2017. [cited by 2020 mai 20]. Available from: https://wearesocial.com/special-reports/digital-in-2017-globaloverview.

Gohn MG. Educação não-formal, participação da sociedade civil e estruturas colegiadas nas escolas. Ensaio: aval. pol. públ. Educ., 2006; 14 (50): p. 27-38.

International Organization for Standardization: ISO 14001: 2015 Environmental management systems, 2015. [cited by 2021 jan 04]. Available from: https://www.iso.org/standard/60857.html.

Kampf G, Todt D, Pfaender S, Steinmann E. Persistence of coronaviruses on inanimate surfaces and their inactivation with biocidal agents. Journal of Hospital Infection. 2020; 104: 246- 251.

Macedo MAAPT, Campos MCP. Educação Ambiental e Resíduos Sólidos Urbanos: Caminho para um Futuro Sustentável. EDUSER: revista de educação, 2015;7(2).

Mauch AGD, Costa, JEM, Silva KM, Andrade LBSO, Almeida LL, Araujo SL, Souza SPDE, Nunes TAR, Souza VR. A utilização das redes sociais digitais no cuidado psicossocial infantojuvenil, diante da pandemia por COVID-19. Healh Residencies Journal. 2020; 1 (2).

Oliveira FR, Santos RF, França SLB, Rangel LAD. Strategies and Challenges for the Circular Economy: a Case Study in Portugal and a Panorama for Brazil. Brazilian Archives of Biology and Technology, 2020; 63.

Parra JH, Salton KZ, Dal Bosco TC, Galo AS, Sudo CH. Mídias sociais como estratégias de educação ambiental para a promoção da coleta seletiva. Anais Do Congresso Sul-Americano de Resíduos Sólidos e Sustentabilidade, 2019; 2.

Pimentel ASO, Le Boudec RM, Leal A.B. metodologia de ensino sob a ótica da qualidade total empregando o ciclo PDCA. Anais do XXXV Congresso Brasileiro de Educação em Engenharia, COBENGE, 2007

Pugliesi E, Santiago CD, Leite WCA. Gestão de resíduos sólidos e a pandemia COVID-19: (des)preparo para enfrentamento da crise. In: Valencio N, de Oliveira CM, editors. COVID-19: crises entremeadas no contexto de pandemia (antecedentes, cenários e recomendações). São Carlos: UFSCar; 2020. p. $135-150$.

Programa das Nações Unidas para o Desenvolvimento - PNUD. Objetivos de Desenvolvimento Sustentável, 2015 [cited by 2020 mar 09]. Available from: https://nacoesunidas.org/.

Silva CMR, Filho JAC, Freire RS. Instagram e educação: a aprendizagem significativa de língua estrangeira em contextos não-formais de ensino. Anais dos Workshops do VII Congresso Brasileiro de Informática na Educação, WCBIE, 2018. 
Sousa Júnior JH, Raasch M, Soares JC, Ribeiro LVH AS. Da desinformação ao caos: uma análise das Fake News frente à pandemia do Coronavírus (COVID-19) no Brasil. Cadernos de Prospecção: Salvador, 2020;13, (2): p. 331-346.

Tozoni-reis MFC. Temas ambientais como "temas geradores": contribuições para uma metodologia educativa ambiental crítica, transformadora e emancipatória. Educar em Revista, Setor de Educação da Universidade Federal do Paraná: Curitiba, 2006;(27): p. 93-110.

Van Doremalen N, Bushmaker T, Morris DH, Holbrook MG, Gamble A, Williamson BN, Tamin A, Harcourt JL, Thornburg NJ, Gerber SI, Lloyd-Smith JO. Aerosol and surface stability of SARS-CoV-2 as compared with SARS-CoV-1. N Engl J Med. 2020; 382(16), p. 1564-1567.

Werhmuller CM, Silveira IF. Redes Sociais como ferramentas de apoio à Educação. Anais do Seminário Hispano Brasileiro. São Paulo, 2012; 3: p. 594-605.

World Health Organization. Water, sanitation, hygiene and waste management for the COVID-19 virus, 2020. Genebra: World Health Organization. [cited by 2020 mar 3]. Available from: https://apps.who.int/iris/bitstream/handle/10665/331499/WHO-2019-nCoV-IPC_WASH-2020.2eng.pdf?sequence $=12$ isAllowed $=y$.

World Health Organization. Considerations for quarantine of individuals in the context of containment for coronavirus disease (COVID-19), 2020. Geneva: World Health Organization. [cited by $2020 \mathrm{mar}$ 19]. Available from: https://www.who.int/publications/i/item/considerations-forquarantine-of-individuals-in-the-context-of-containment-for-coronavirus-disease-(covid-19).

\section{AUTHORSHIP CONTRIBUTIONS}

\section{1-Yasmin Coelho de Freitas}

Master's student in the Postgraduate Program in Sustainable Technologies https://orcid.org/0000-0002-6112-0730 | E-mail: yasmincoelhodefreitas@gmail.com Contribuition: Conceptualization, Investigation, Project administration and Writing - original draft

\section{2-Francisco de Assis Ferreira}

Master's student in the Postgraduate Program in Sustainable Technologies https://orcid.org/0000-0003-2214-1966 | E-mail: franciscodeassis@gmail.com Contribuition: Conceptualization, Investigation, Project administration and Writing - original draft

\section{3- Carlos Eduardo Batista Groner}

Master's student in the Postgraduate Program in Sustainable Technologies https://orcid.org/0000-0003-3801-8620 | E-mail: carlos.groner@ifes.edu.br Contribuition: Conceptualization, Investigation and Writing - original draft

\section{4-Igor Tristão Azevedo}

Master's student in the Postgraduate Program Program in Sustainable Technologies 
https://orcid.org/0000-0003-2372-1356 | E-mail: igor_ta@hotmail.com

Contribuition: Conceptualization, Formal analysis and Writing - original draft

\section{5-Jacqueline Rogéria Bringhenti}

Professor of the Sanitary and Environmental Engineering Course

https://orcid.org/0000-0002-2557-9966 | E-mail: jacquelineb@ifes.edu.br

Contribuition: Conceptualization, Supervision, Project administration and Writing - review \& editing

\section{6-Adriana Marcia Nicolau Korres}

Professor of the Sanitary and Environmental Engineering Course

https://orcid.org/0000-0002-7882-3475 | E-mail: jacquelineb@ifes.edu.br

Contribuition: Conceptualization, Supervision, Project administration and Writing - review \& editing

\section{HOW TO QUOTE THIS ARTICLE}

Freitas, Y. C. F. et.al. Instagram as a tool for disseminating sustainable practices: an experience report. Revista de gestão, educação e tecnologia ambiental, Santa Maria, v.25, e2, 2021. Available from: https://doi.org/10.5902/2236117063440. Accessed: Month Abbreviated. Day, year. 